\title{
Effect of Harvesting Time and Water Retting Fiber Processing Methods on the Physico-mechanical Properties of Kenaf Fiber
}

\begin{abstract}
Hazwani Husna Abdullah, ${ }^{a}$ Sarani Zakaria, ${ }^{a} *$ Noor Intan Saffinaz Anuar, a,b Kushairi Mohd Salleh, ${ }^{\mathrm{a}, *}$ and Sharifah Nabihah Syed Jaafar ${ }^{\text {a }}$

Fiber processing is an important factor that affects the physical and mechanical properties of long kenaf fiber. The physical-mechanical properties, such as color, tensile strength, and moisture regain (MR), are the main characteristics that influence the processing and performance on the final products from kenaf fiber. The objective of this research was to evaluate the physical and mechanical properties of kenaf fiber at the week of planting, with different processing methods that were planted in a selected location in Malaysia. Kenaf fiber was separated by the water retting method, where the combination of water retting and mechanical retting was based on the available facilities and proficiency at the sites. The tensile strength and chemical composition of kenaf fiber showed large variability for every location collected and for each processing technique used. Visual observations and color testing indicated that kenaf fiber with extended water immersion exhibited higher lightness and smoother fiber. A slight reduction in moisture regains was observed with increased crystallinity index. The differences among properties of the kenaf fiber that were influenced by harvesting week and processing methods could give some references and overview for the planters, suppliers, industries, and researchers to identify the suitable fiber quality for their targeted final products.
\end{abstract}

Keywords: Chemical composition; Color testing; Moisture regain; Mechanical separation

Contact information: a: Bioresources and Biorefinery Laboratory, Faculty of Science and Technology, Universiti Kebangsaan Malaysia, 43600 UKM Bangi, Selangor, Malaysia; $b$ : Fiber and Biocomposite Centre, Malaysian Timber Industry Board, Banting 42700, Selangor, Malaysia;

*Corresponding authors: szakaria@ukm.edu.my, kushairisalleh@gmail.com

\section{INTRODUCTION}

In Malaysia, kenaf was introduced as an alternative crop to farmers while the government slowly tried to reduce tobacco plantations due to environmental awareness and economic consideration (Izran et al. 2014; Misnon et al. 2014). The National Tobacco and Kenaf Board (NKTB) is the national agency that has been established to coordinate the implementation of policies, programs development, and commercialization of kenaf and tobacco. Universities, research institutes, and industries also have become progressively involved in the research on kenaf, covering the downstream, midstream, and upstream area. The understanding of the fiber properties is essential to ensure they meet the industry concerns and provide acceptable requirements and standards to the end products. Moreover, this knowledge could also be used as a guideline in the selection of fiber treatment. There have been extensive studies and developments conducted and reported on kenaf (Hibiscus cannabinus L.) (H'ng et al. 2009). Kenaf has been recognized as a crop 
with great potential after a few established commodity plant periods due to a shortage of wood fiber from virgin forests, and because of its excellent mechanical properties.

Kenaf can be harvested within 3 to 6 months as green or dry material and it consists of 25 to $40 \%$ bast and 60 to $75 \%$ core. In terms of mechanical properties, kenaf exhibits almost similar properties to jute fiber with more lustrousness and brighter color (Anuar et al. 2018). Superior strength of kenaf bast fiber makes it suitable for high performance products, such as reinforced composites, while the core material should be infrequently utilized due to its moderate properties (Chan et al. 2013). Kenaf harvesting is usually practiced either by using machines, such as a combination of mower conditioners and baling equipment, a sugarcane-type harvester, and 4GL-180II machines (Pari et al. 2015), or manually by hand. For the harvesting process, some plantation sites still use manual techniques that are labor-intensive, making them less profitable (Dauda et al. 2013). During the harvesting process, kenaf stems were cut near the plant base approximately 3 to $5 \mathrm{~cm}$ above the soil, where it can maximize the fiber yield and fiber length (Singh 2010). The beginning of the flowering stage is the best time for kenaf harvesting for good fiber quality and high yield production. Iii et al. (2002) mentioned that the protein content, the kenaf leaf, and stalk percentage, are related to the age of kenaf during harvesting time. After the harvesting process, kenaf stem or stalk was biologically or chemically retted to extract the bast part. Retted fibers were manually stripped from the stem. Mechanical separation can be conducted prior to the retting process, depending on the equipment and machines available. Then, kenaf fiber was washed and dried well before being transported for further processing (Grubben 2004).

Different fiber separation techniques produce fibers with differences in physical, mechanical, and morphological properties, which subsequently influence the properties of the final product. The separation between the bast and core parts is conducted with various methods such as mechanical separation and retting process. During mechanical separation, fluted rollers are used to break and crush the woody core, while the remaining bast fibers are converted into ribbon form. In contrast, the retting process is used to remove the gum component, such as lignin, hemicelluloses, pectin, and other impurities, while keeping the cellulose in good condition ( $\mathrm{Yu}$ and $\mathrm{Yu}$ 2007). Traditionally, kenaf stems are kept on the field (dew retting) or immersed in the pond/tank/river (water retting) for two or three weeks. Microbial activities in the retting process break down the fiber parts by degrading and softening the pectins that glue the plant tissues together and release individual fibers (Md. Tahir et al. 2011). Dhulina et al. (2019) summarized that long kenaf fiber could be produced by dew, enzymatic, chemical, and water retting, while mechanical retting provided short or twisted fiber. A combination of mixing processes, such as chemical and enzymatic retting, was introduced to improve the fiber quality, mechanism, and environmental issues of the traditional retting process. However, the recent alteration on the retting process showed multiple advantages and disadvantages in terms of cost, energy used, and fiber quality itself. The final product from the fiber produced should be taken into consideration in the selection of the retting method.

To date, research on the suitability of each location, soil condition, climate, fiber processing, and machines used are still ongoing to obtain the best results for fiber quality and yield. In terms of fiber processing, each location is practicing different methods based on the local infrastructure, logistics, and guidelines provided by NKTB. The information on the physical and mechanical properties of Malaysia cultivated kenaf has gone through different processing techniques, as it is important for the planters, suppliers, industries, and researchers to obtain the good quality of the fiber. In this study, kenaf fibers were collected 
from selected locations throughout Malaysia and were evaluated. This procedure was carried out to generate information on the mechanical, physical, and optical properties of kenaf fiber at different harvesting periods and fiber processing methods on selected processing locations in Malaysia.

\section{EXPERIMENTAL}

\section{Kenaf Fiber Preparation}

For the sample collection of fiber, kenaf were harvested at 12 and 16 weeks after planting (WAP) and was obtained from five states in Malaysia: Pahang (PH-1), Johor (JH2), Perlis (PR-3), Terengganu (TG-4), and Kelantan (KN-5). The fibers were air-dried until the moisture content reached below $12 \%$ before testing. The samples were kept in a closed dark container to minimize degradation and color changing. Water retting was conducted at local fiber processing sites where the duration (days), type of water, type of container, pre-treatment process, and drying period were conducted differently according to the local fiber processing site practice. The processing of the samples is simplified in Table 1.

Table 1. Kenaf Processing Stages by States in Malaysia

\begin{tabular}{|c|c|c|c|c|}
\hline \multirow[t]{2}{*}{ Sample } & \multicolumn{4}{|c|}{ Processes } \\
\hline & Stage 1 & Stage 2 & Stage 3 & Stage 4 \\
\hline $\mathrm{PH}-1$ & $\begin{array}{c}\text { Kenaf } \\
\text { harvesting }\end{array}$ & $\begin{array}{l}\text { Kenaf stem } \\
\text { immersed in } \\
\text { natural pond with } \\
\text { natural water (14 } \\
\text { days) }\end{array}$ & $\begin{array}{l}\text { Separation manually by } \\
\text { hand. Washing with clean } \\
\text { water. }\end{array}$ & Drying \\
\hline $\mathrm{JH}-2$ & $\begin{array}{c}\text { Kenaf } \\
\text { harvesting }\end{array}$ & $\begin{array}{l}\text { Mechanical } \\
\text { separation using } \\
\text { decorticator }\end{array}$ & $\begin{array}{c}\text { The ribbon was immersed } \\
\text { in the water ( } 10 \text { days) in } \\
\text { the pond. }\end{array}$ & Drying \\
\hline PR-3 & $\begin{array}{c}\text { Kenaf } \\
\text { harvesting }\end{array}$ & $\begin{array}{l}\text { Mechanical } \\
\text { separation using } \\
\text { decorticator }\end{array}$ & $\begin{array}{l}\text { The ribbon was immersed } \\
\text { in the water ( } 8 \text { days) in the } \\
\text { polytank. Water for } \\
\text { immersion was collected } \\
\text { from the pond and ditch. }\end{array}$ & Drying \\
\hline TG-4 & $\begin{array}{c}\text { Kenaf } \\
\text { harvesting }\end{array}$ & $\begin{array}{l}\text { Mechanical } \\
\text { separation using } \\
\text { decorticator }\end{array}$ & $\begin{array}{l}\text { The ribbons were } \\
\text { immersed in the water ( } 10 \\
\text { days) in the pond } \\
\text { connected to the small } \\
\text { river stream. } \\
\text { Fibers were washed in the } \\
\text { running river stream. }\end{array}$ & Drying \\
\hline $\mathrm{KN}-5$ & $\begin{array}{c}\text { Kenaf } \\
\text { harvesting }\end{array}$ & $\begin{array}{l}\text { Mechanical } \\
\text { separation using } \\
\text { decorticator }\end{array}$ & $\begin{array}{l}\text { The ribbon was immersed } \\
\text { in the water ( } 14 \text { days) in } \\
\text { the pond with rain and bore } \\
\text { water. Fibers were washed } \\
\text { with clean water. }\end{array}$ & Drying \\
\hline
\end{tabular}




\section{Characterization}

Morphology of kenaffiber

The morphological observations of the kenaf fiber were investigated using a scanning electron microscope (SEM) LEO 1450VP (Carl Zeiss Microscopy GmbH, Jena, Germany. Prior to scanning, the samples were sputter-coated with gold (Polaron SC7680; Quorum Technologies Ltd., East Sussex, United Kingdom). The diameters of the fiber were measured during the SEM observation at 200X magnification. A Dino-Lite Pro microscope AM-413ZT (Dino-Lite, Torrance, CA, USA) was used to capture surface images of kenaf fiber strands at 70X magnification.

\section{Chemical analysis}

The composition of cellulose, hemicelluloses, lignin, ash, and extractives of kenaf fiber was measured according to TAPPI Test Methods: TAPPI T203 cm-99 (1999), TAPPI T222 (1999), TAPPI T244 (1998), and ASTM D1107-96 (2001), respectively. Hot-water solubility of kenaf fibers was conducted to measure extraneous components such as sugars, starches, and others. Samples were ground using a Microfine Grind Drive (IKA-Werke $\mathrm{GmBH}$, Staufen, Germany) and placed in the sieve machine. Samples that passed through at BS 40-mesh sieve and retained at BS 60-mesh were collected for further processing.

\section{Moisture regains}

Moisture regains (MR) for kenaf fiber were conducted according to ASTM D249507 (2007). Approximately $10 \mathrm{~g}$ of ground kenaf fiber was placed in the oven at $105^{\circ} \mathrm{C}$ and dried for $24 \mathrm{~h}$. The fibers were weighed and then moved into the humidity chamber with the relative humidity set at $65 \%$ and at a temperature of $20{ }^{\circ} \mathrm{C}$. After $8 \mathrm{~h}$, the weights of the fibers were measured. The process of weighing, drying, and cooling the fibers was repeated until the change in mass between two successive weighings was less than $0.1 \%$ of the specimen mass.

$X$-ray diffraction $(X R D)$.

The crystallinity percentage of the kenaf fibers was determined by using a Bruker AXS X-ray diffractometer (AXS GmbH, Karlsruhe, Germany). The $\mathrm{Cu} \mathrm{K} \alpha$ radiation and anode voltage were at $(\lambda=0.154 \mathrm{~nm})$ and $40 \mathrm{kV}$, respectively. The percentage of the crystallinity index was automatically measured using the instrument software (Bruker AXS GmbH, V.1.2, Staufen, Germany).

\section{Color testing}

The color examination of kenaf fiber was carried out using a portable CR-410 Chroma Meter (Fig. 1) (Konica Minolta Inc., Osaka, Japan), which is designed to evaluate the color of the objects and the texture and surface conditions. The diameter of the measurement or illumination area of this Chroma meter is $50 \mathrm{~mm}$ (Kassim et al. 2012). In the color space defined by the International Commission on Illumination (CIE), $L^{*}$ indicates the lightness of the object, while $a^{*}$ and $b^{*}$ are the chromaticity coordinates. In the color space diagram, the $a^{*}$ and $b^{*}$ indicate the color direction: $+a^{*}$ is the red direction, $-a^{*}$ is the green direction, $+b^{*}$ is the yellow direction, and $-b^{*}$ is the blue direction. Five bundles of kenaf fiber were randomly chosen and placed parallel and close-together in five metal plates. The measurements taken were firmly covered by glass to ensure that the entire gap was covered by kenaf fiber. For each plate, four measurement spots were chosen. The 
calorimeter automatically showed the $L^{*}, a^{*}$, and $b^{*}$ results on the screen. The average readings from all the samples were taken for further analysis.

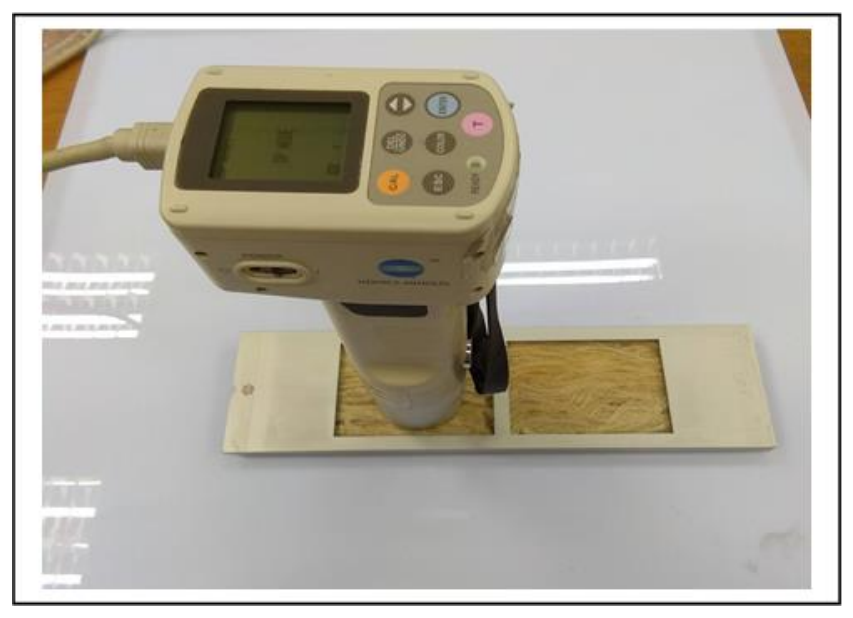

Fig. 1. Measurement taken using Chroma meter 410

\section{Single fiber tensile strength}

The tensile strength testing for single fiber was performed using a universal testing machine Shimadzu AG-X Plus (Shimadzu Corporation, Kyoto, Japan). The tensile strength test was conducted based on ASTM D3822-01 (2001). Bundles of fiber were manually separated one-by-one and temporarily placed on a glass slide. Double-sided tape was used to attach the fiber to the glass slide. A total of 40 single fiber diameter was measured using an Olympus BX43 Biological Microscope (Olympus Corporation, Tokyo, Japan) at 10X magnification. Finally, a single fiber was directly clamped between two blocks on both ends. The gauge length was set at $10 \mathrm{~mm}$. A load cell of $10 \mathrm{~N}$ was used to measure the force. For each sample, 40 readings were calculated based on the load $(\mathrm{N})$ per area of the fiber.

\section{RESULTS AND DISCUSSION}

\section{Morphology Properties of Kenaf fiber}

Samples were collected at different periods (12 and 16 WAP) based on the schedule provided by NKTB. Except for the sample from PH-1, the other states underwent mechanical separation (decorticator) before water retting. The variations in the samples collection in terms of color, physical appearance, MR, and others were due to several factors such as the easiness of processing operation, the cost of fiber transportation, water consumption, and the storage space required. Different physical appearances and colors can be observed for all collected kenaf fibers, as shown in Fig. 2.

The different sequences in processing activities contributed to the difference in the kenaf fibers' appearances. It was expected to be a small difference in terms of fiber surface roughness according to the retting process at selected locations. As shown in Fig. 2e, visually kenaf fibers PH-1 showed smoother and lighter color. At the processing site of $\mathrm{PH}-1$, kenaf stem was completely submerged in a big pond with water collected from rain, stream, and underground water. Leaves, shoots, and flowers from the kenaf stem were naturally retted during the water retting process. After 14 days, the kenaf stems were taken 
out from the pond, followed by the manual separation of bast and core by hand. The fibrous bark was completely removed, and the core part successfully separated from the bast manually. Md. Tahir et al. (2011) reported the existence of pectynolytic bacteria in the decomposition of pectineus substances during water retting produced a high-quality fiber with greater uniformity compared to the mechanical extraction and dew retting. Furthermore, it was reported that the conditions for bacterial growth and activities were found to be more consistent in water retting, which produced the uniform colonization of bacteria and resulted in better fiber quality (Nair et al. 2013).

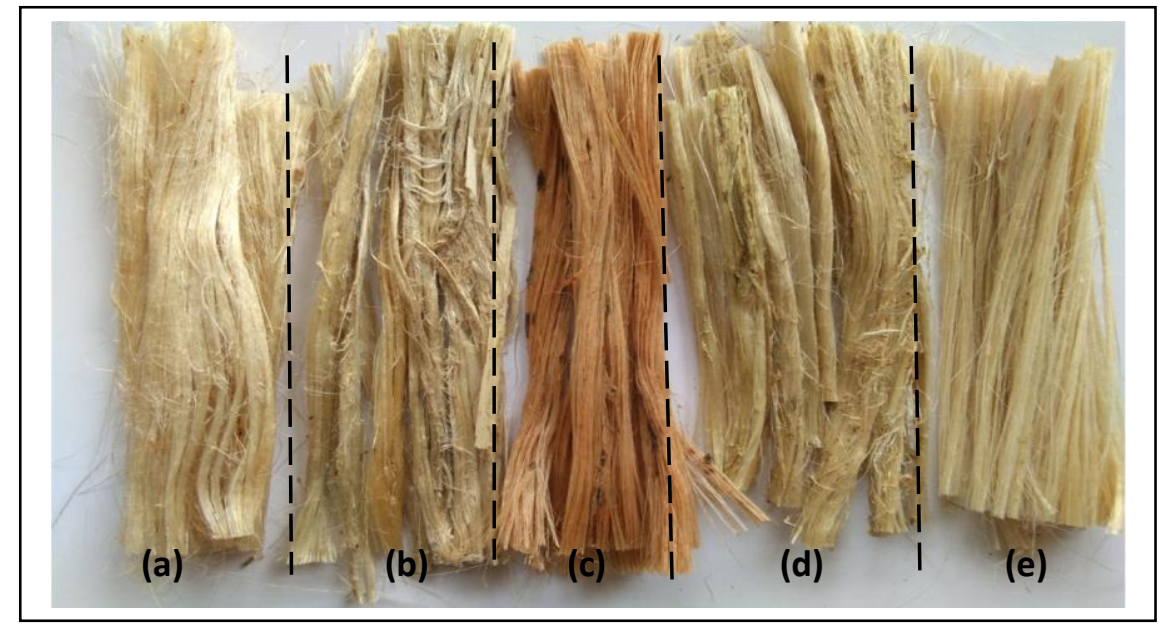

Fig. 2. Kenaf fiber sample collected: a) $\mathrm{KN}-5$, b) JH-2, c) PR-3, d) TG-4, and e) PH-1

As shown in the green circle in the figures, there were lots of cores left, more deteriorations, and unused substances attached to the kenaf fiber of JH-2, PR-3, and TG-4 (Figs. 3a, b, and e). The circle is shown in Fig. 3e, which represents kenaf fibers of TG-4, shows unclean kenaf fibers with fibrous bark and cortical cell due to the short immersion days observed. The fibers of TG-4 were also coarser and possessed lower uniformity on the surface. The spot of deterioration exhibited in Fig. 3b of the PR-3 sample was spotted, and incomplete separation of fiber with unused substances can be seen in Fig. 3a and c representing samples from JH-3 and KN-5, respectively. Meanwhile, more broken core and kenaf fibrous bark skin were found in the kenaf fiber of JH-2, KN-5, and TG-4 as observed in Fig. 3a, c, and e, respectively, due to the mechanical extraction activity conducted before the water retting process. Mechanical extraction-water retting technique is also known as ribbon retting and has been conducted widely on bast fiber, such as kenaf and jute, in Bangladesh. The requirement of water is almost half in volume, and the duration time of mechanical extraction can be reduced to 4 or 5 days (Sarkar and Sengupta 2015). Md. Tahir et al. (2011) stated that even though the mechanical extraction could produce a massive volume of fiber, the quality of the fiber tends to be lower and produced shorter fibers. Furthermore, by conducting mechanical extraction, the removal of cementing compounds in fibers, such as waxes, hemicellulose, and lignin, are not complete (Hulle et al. 2015).

Scanning electron microscope analysis was conducted to observe the fiber structure surface after the retting process. Figure 4 shows the longitudinal images of kenaf fibers surface. In general, kenaf fiber from all locations at 12 and 16 WAP showed straight, rough, and clear physical appearances with less fibrillation or pulled out effect because there was no chemical or mechanical treatment conducted. 

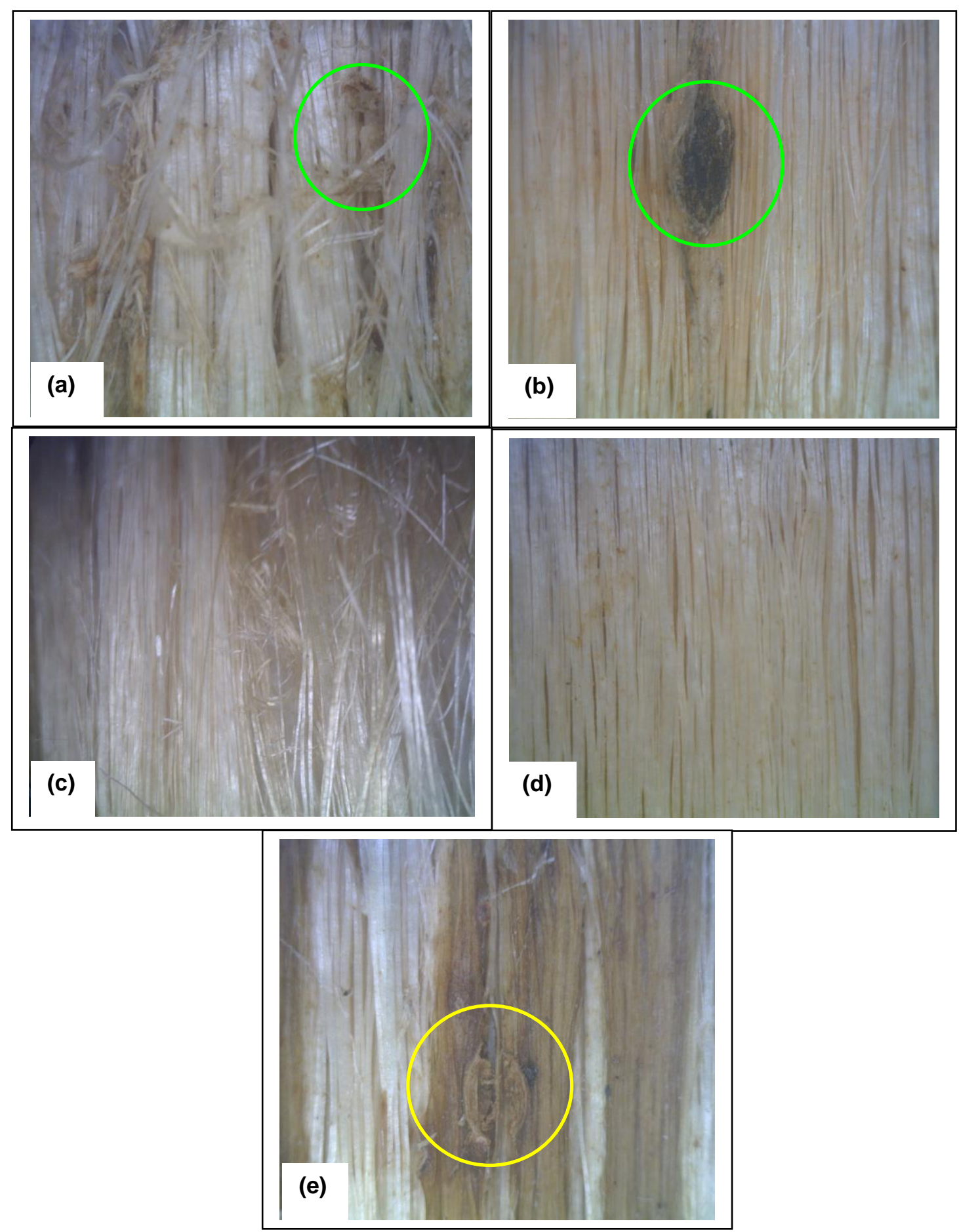

Fig. 3. Kenaf fiber images from a) JH-2, b) PR-3, c) KN-5, d) PH-1, and e) TG-4 at 16 WAP

The SEM micrograph of kenaf fiber presented in Fig. 4a of PH-1 at 16 WAP clearly shows fewer surface impurities compared to the sample in Fig. 4b of PR-3 at 16 WAP. It was found that from the processing site, kenaf fiber taken from PR-3 were air-dried horizontally on the mat, which might lead to further exposure to the dust and soil. The presence of more impurities and void affects the appearance, processability, and reduces 
the adhesion capability of the fiber, lowering the strength properties of the final products. The impurities and dust might increase on the surface of the kenaf fiber if the kenaf plant was exposed longer to the environment after harvesting and during the processing activities and improper storage (Das et al. 2014).
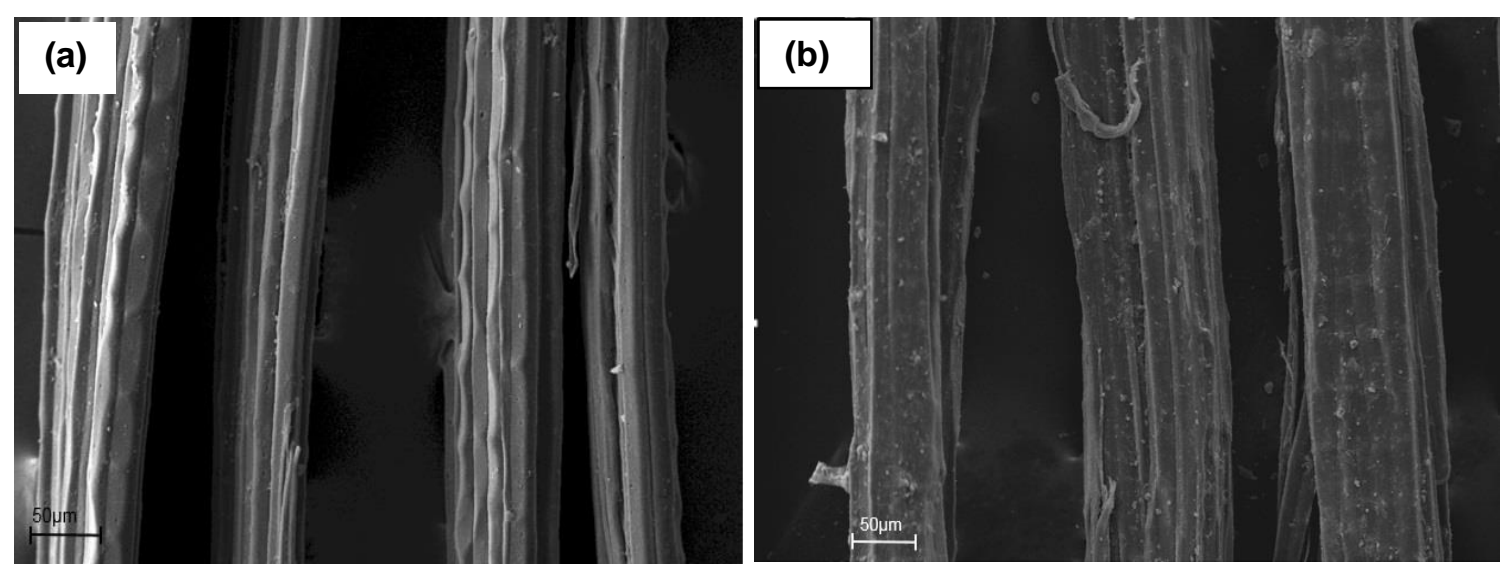

Fig. 4. Longitudinal images of kenaf fiber: (a) PH-1 and (b) PR-3 at 16 WAP

Chemical compositions of retted kenaf fiber

The evaluations of chemical compositions in kenaf fiber from different processing methods and harvesting durations are necessary because lignocellulosic components are the foremost factor in influencing biocomposite and textile product properties. Table 2 summarizes the chemical compositions of kenaf fiber at 12 and 16 WAP.

Table 2. Chemical Compositions of Kenaf Fiber

\begin{tabular}{|c|c|c|c|c|c|c|c|c|}
\hline \multirow[t]{2}{*}{ Sample } & \multirow[t]{2}{*}{ WAP } & \multirow[t]{2}{*}{$\begin{array}{l}\text { Lignin } \\
(\%)\end{array}$} & \multirow{2}{*}{$\begin{array}{c}\alpha- \\
\text { cellulose } \\
(\%)\end{array}$} & \multirow[t]{2}{*}{$\begin{array}{c}\text { Hemicelluloses } \\
\text { (\%) }\end{array}$} & \multirow[t]{2}{*}{$\begin{array}{l}\text { Ash } \\
(\%)\end{array}$} & \multicolumn{3}{|c|}{$\begin{array}{c}\text { Extractives } \\
(\%)\end{array}$} \\
\hline & & & & & & Hot & Cold & $\begin{array}{l}\text { Alcohol- } \\
\text { benzene }\end{array}$ \\
\hline \multirow[b]{2}{*}{$\mathrm{PH}-1$} & 12 & 17.76 & 54.76 & 37.73 & 0.40 & 3.48 & 0.19 & 2.21 \\
\hline & 16 & 15.05 & 55.48 & 35.41 & 0.29 & 4.64 & 0.16 & 3.77 \\
\hline \multirow[b]{2}{*}{$\mathrm{JH}-2$} & 12 & 16.94 & 53.58 & 32.17 & 0.92 & 1.12 & 0.34 & 3.42 \\
\hline & 16 & 15.12 & 53.80 & 31.39 & 0.86 & 2.98 & 0.89 & 2.42 \\
\hline \multirow[b]{2}{*}{ PR-3 } & 12 & 17.99 & 55.43 & 25.07 & 2.45 & 2.09 & 1.92 & 2.72 \\
\hline & 16 & 17.97 & 55.94 & 24.14 & 1.84 & 4.74 & 1.41 & 2.33 \\
\hline \multirow[b]{2}{*}{ TG-4 } & 12 & 14.34 & 54.81 & 32.29 & 0.79 & 4.64 & 1.89 & 2.39 \\
\hline & 16 & 16.92 & 56.10 & 31.94 & 0.46 & 4.92 & 1.81 & 4.33 \\
\hline \multirow[b]{2}{*}{$\mathrm{KN}-5$} & 12 & 14.87 & 50.25 & 36.02 & 0.38 & 4.20 & 1.92 & 4.85 \\
\hline & 16 & 14.23 & 50.85 & 28.88 & 0.44 & 5.87 & 1.99 & 2.90 \\
\hline
\end{tabular}

The 16 WAP kenaf fiber had higher $\alpha$-cellulose and lower lignin content compared to the 12 WAP sample, while the content of hemicellulose content was opposite. However, ash and extractives varied slightly according to the length of time planting, locations, and processing methods. The increasing pattern of the cellulose content might be contributed 
by the growth process of the kenaf fiber as they meet their maturity age. Usually, most of the non-woody plants, including kenaf, complete their life cycle within four to six months, depending on the cultivation conditions during the growing season (Kamat et al. 2002). Lower fiber yield and strength were commonly produced when the fibers were harvested under the maturity age. Inversely, the fiber becomes harsh, coarse, and difficult to peel when the kenaf is harvested beyond its maturity stage.

The presence of starch was determined by the hot water solubility procedure (Anuar et al. 2018). The hot water solubility extractives of the 16 WAP kenaf fiber was higher than 12 WAP at all selected locations. In comparison, the results on the extraction in hot water showed similar trends with the data reported by Ang et al. (2010), where the presence of extracted materials in bast kenaf fiber was higher in the 4.5 months old kenaf compared to the 3.5 months old. Agronomic practices and the amount of contaminants are usually attributed to the mineral contents in plant fibers. Clearly, the sample taken from PR-3 had a higher ash content (1.84 to 2.45\%) compared to samples taken from other locations. The higher ash content might be attributed to the reddish soil of the kenaf plantation site. The study conducted by Abdul et al. (2001) explained that most of the plantation site in PR-1 was surrounded by dark red soil, which resulted from the weathering process of a limestone hill nearby. The 'red soil' consists of four major elements, which are $\mathrm{SiO}_{2}$ (42.3 to $92.3 \%$ ), $\mathrm{TiO}_{2}$ (0.4 to $1.99 \%$ ), $\mathrm{Fe}_{2} \mathrm{O}_{3}$ (1.09 to $7.9 \%$ ), and $\mathrm{Al}_{2} \mathrm{O}_{3}$ (3.2 to $30.35 \%$ ). All these heavy metals were higher than critical level and might be harmful especially to agricultural activities (Abdul et al. 2001).

\section{Moisture regain and crystallinity of cellulose in kenaf fiber}

The MR property is important to evaluate the properties and suitability of the fibers, especially if they are to be used in the textile and paper industry, and composites production. The MR results can also be used as a reference during the fiber processing, storage, and manufacturing to ensure the fibers were appropriately handled to minimize the deteriorations of the fibers. Figure 5 illustrates the samples of 12 WAP, which showed higher MR percentage compared to the $16 \mathrm{WAP}$. The MR of the retted fiber ranged from 8.33 to $10.02 \%$ according to the locations.

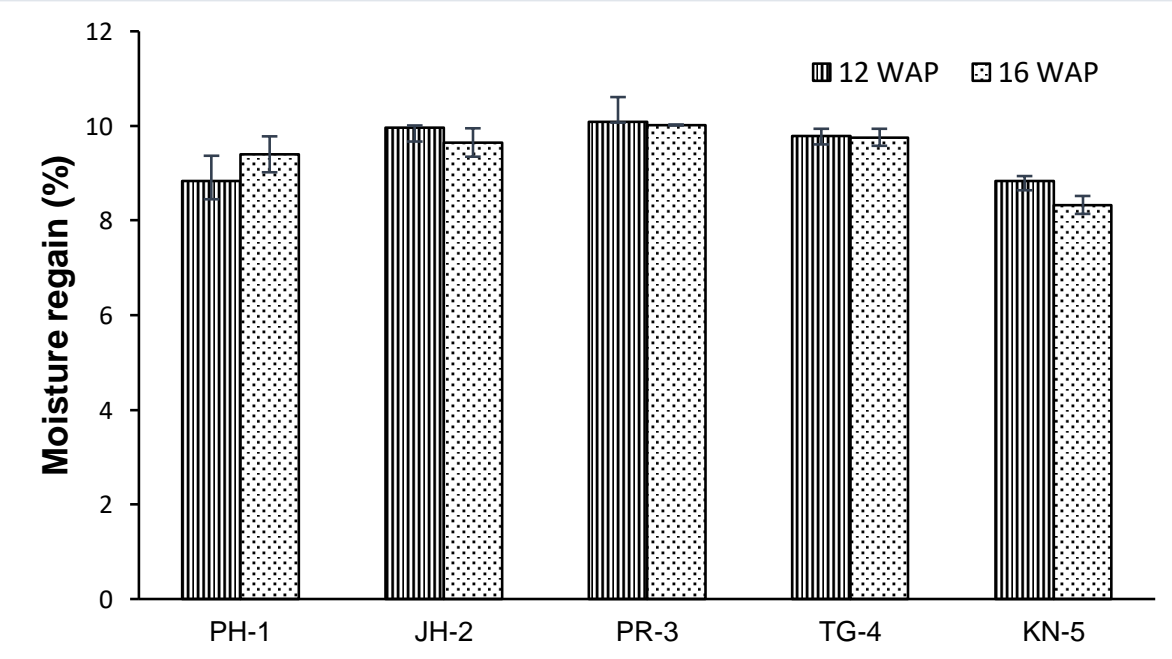

Fig. 5. Moisture regain percentage of kenaf fiber at 12 and 16 WAP 
The absorption behavior of the plant fibers generally occurred on the components with polar groups such as cellulose, hemicellulose, and pectin. These components could also influence the hygroscopicity behavior of the fiber (Célino et al. 2014). Hemicellulose is the main contributor to the accessibility of water into the fiber, due to the fully amorphous polysaccharide structure and high open structure of the hydroxyl $(-\mathrm{OH})$ and acetyl $\left(\mathrm{C}_{2} \mathrm{H}_{3} \mathrm{O}\right)$ groups (Fotouh et al. 2015; Binshan et al. 2018). This is in agreement with Komuriah et al. (2014), who reported their plotted regression graph of moisture gain $v s$. hemicellulose content, showing the increase of hemicellulose leads to incremental of water absorption in many types of natural fiber. In contrast, cellulose as the major component in natural fiber has small contributions to the absorptiveness of water due the existence of small amounts of $-\mathrm{OH}$ groups as cellulose is a semi-crystalline polysaccharide. Table 3 shows the crystallinity index of 12 and 16 WAP of cellulose in kenaf fibers. Fibers with higher crystallinity had small holes and strong bonding force between the fibers (Wang et al. 2016); hence, less MR were observed here.

Table 3. Crystallinity Index of 12 and16 WAP Kenaf Fibers

\begin{tabular}{|c|c|c|}
\hline \multirow{2}{*}{ Sample } & \multicolumn{2}{|c|}{ Crystallinity Index (\%) } \\
\cline { 2 - 3 } & 12 WAP & 16 WAP \\
\hline PH-1 & 38.6 & 36.3 \\
\hline JH-2 & 39.1 & 39.3 \\
\hline PR-3 & 43.3 & 44.3 \\
\hline TG-4 & 35.2 & 37.4 \\
\hline KN-5 & 34.8 & 37.7 \\
\hline
\end{tabular}

\section{Color analysis of kenaf fiber}

By using a colorimeter, the color measurement of natural fiber was analyzed technically using a color space diagram. Table 4 shows the lightness of all samples of kenaf fibers. The PH-1 and KN-5 samples recorded lightness with values more than 70 . The higher the reading of $L^{*}$ (lightness), the closer the samples to the color white, while the lower the $L^{*}$ value, the color approached black. The sample of 12 WAP recorded a higher $L^{*}$ value compared to the 16 WAP for all locations. From the survey conducted at the processing site earlier, it can be concluded that the high $L^{*}$ value for $\mathrm{KN}-5$ and PH-1 might be due to several factors such as the proper washing process of the kenaf fiber after water retting or the fact that the outer bast was almost completely removed during the retting process. The manual washing and cleaning process of the retted kenaf fiber conducted by workers produced a clean fiber. The dark layer of outer bast, which promoted the formation of dark fibers, was completely discarded during these processes. In contrast, the lighter color of the PH-1 and KN-5 kenaf fiber were also contributed by longer water retting duration, which led to better removal of the outer bast layer, core, dust, and other impurities. This is supported by the work of Ruan et al. (2015), which indicated that in the extended duration of water retting, flax fiber showed the lightest color in the extended duration of water retting due to the dissolving of colored material and contaminated substances. Das et al. (2014) clearly stated that factors, such as retting conditions, water, and washing quality, might influence the color of all bast fiber after the drying process. The different fiber processing activities at different locations noticeably affected the obvious differences in the color of kenaf fiber, which is supported by the ANOVA $(\mathrm{P}<$ 
$0.05)$ value at 0.03 , as tabulated in Table 5. The reddish color of kenaf fiber collected from PR-3, as can be seen in Fig. 2c, is influenced by the "red sand" in the plantation site. This red sand is also known as terra rossa soil (Abdul et al. 2001). During the harvesting, mechanical extraction, water retting, and drying process, kenaf fiber was exposed to the red sand and consequently gave the red color to the kenaf fiber.

Table 4. The $L^{*}, a^{*}$, and $b^{*}$ Measurement of Retted Kenaf Fiber

\begin{tabular}{|c|c|c|c|c|}
\hline Location & WAP & $L^{*}$ & $a^{*}$ & $b^{*}$ \\
\hline \multirow{3}{*}{ PH-1 } & 12 & 71.89 & 1.21 & 14.01 \\
\cline { 2 - 5 } & 16 & 69.65 & 2.07 & 14.42 \\
\hline \multirow{3}{*}{ JH-2 } & 12 & 69.18 & 1.84 & 15.02 \\
\cline { 2 - 5 } & 16 & 66.89 & 2.05 & 13.58 \\
\hline \multirow{2}{*}{ PR-3 } & 12 & 64.6 & 2.52 & 12.63 \\
\hline \multirow{2}{*}{ KN-4 } & 16 & 64.58 & 2.49 & 12.63 \\
\hline & 12 & 68.17 & 1.24 & 12.84 \\
\hline & 16 & 67.17 & 1.14 & 12.13 \\
\hline & 12 & 72.3 & 2.52 & 14.47 \\
\hline & 16 & 72.2 & 1.8 & 14.12 \\
\hline
\end{tabular}

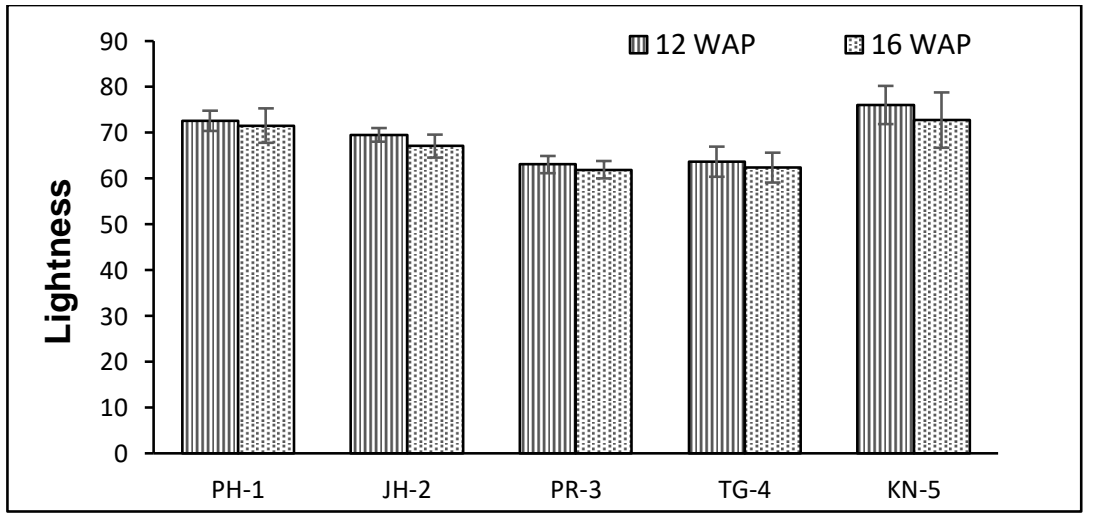

Fig. 6. Lightness values of kenaf fibers at 12 and 16 WAP

Figure 6 shows the lightness values of kenaf fibers at 12 and 16 WAP. As shown in Fig. 6, the sample with the highest lightness was KN-5, while the darkest was PR-3. The differences in lightness between the samples might be attributed to the reaction of the iron in the water with the kenaf fiber during the retting process. It was found that the retting process of the PR-3 sample was conducted in a small polytank filled with water from the local pond and ditch. Because the local kenaf plantation and processing are conducted on the red soil area, the water collected from the local ponds and ditch for the retting process might have had a high content of iron and consequently influenced the reddish dark color of the fiber produced (Abdul et al. 2001). Das et al. (2014) and Buddhadeb (2013) suggested that the combinations of the ferrous iron and the tannin that deliberated from the fibers imparts the dark color to the fiber. Moreover, NIIR (2005) described that the reaction of the iron with "phenolic acid lignin" in fiber resulted in the variations of color for the kenaf fiber. Therefore, it can be concluded that slow-moving clear water with the low content of minerals, such as salt, iron, and calcium, is the best water retting conditions for the superior quality of kenaf fiber. 
Table 5. ANOVA of Kenaf Fiber Lightness

\begin{tabular}{|c|c|c|c|c|c|}
\hline $\begin{array}{c}\text { Source of } \\
\text { Variance }\end{array}$ & DF & SS & MS & F-Value & P-Value \\
\hline Location & 4 & 70.552 & 17.6379 & 28.87 & $0.003^{*}$ \\
\hline WAP & 1 & 3.192 & 3.1922 & 5.23 & 0.084 \\
\hline
\end{tabular}

${ }^{*} \mathrm{P}$ - value less than 0.05 is significant

\section{Tensile strength of kenaf fiber}

Figure 7 shows the single fiber tensile strength samples collected at different locations at 12 and 16 WAP. High tensile strength was observed on the kenaf fiber samples collected from PH-1 16 WAP and KN-5 12WAP and 16WAP with the value of 410, 421, and $424 \mathrm{MPa}$, respectively, where the longest kenaf fibers were submerged (14 days). From the observation in the processing site, $\mathrm{PH}-1$ fiber was completely submerged and weighted down with the assistance of a weight-lifting tool in a huge and sufficient depth of pond. In contrast, the KN-5 fiber was submerged in the large cemented bag pond filled up with rain and bore water for 14 days. These water retting conditions avoided the damage and deterioration of kenaf fiber and subsequently led to better fiber quality and strength. Chaudhury et al. (2007) summarized that several factors need to be considered during the water retting process to obtain good quality of fiber, such as water temperature, climate and weather condition, source and depth of water, and, last but not least, the quantity of stalks in ratio to volume of water. Furthermore, these two kenaf fiber samples of PH-1 and $\mathrm{KN}-5$ also were smaller in diameter in comparison to the other samples that were 67.5 and $57.8 \mu \mathrm{m}$, respectively.

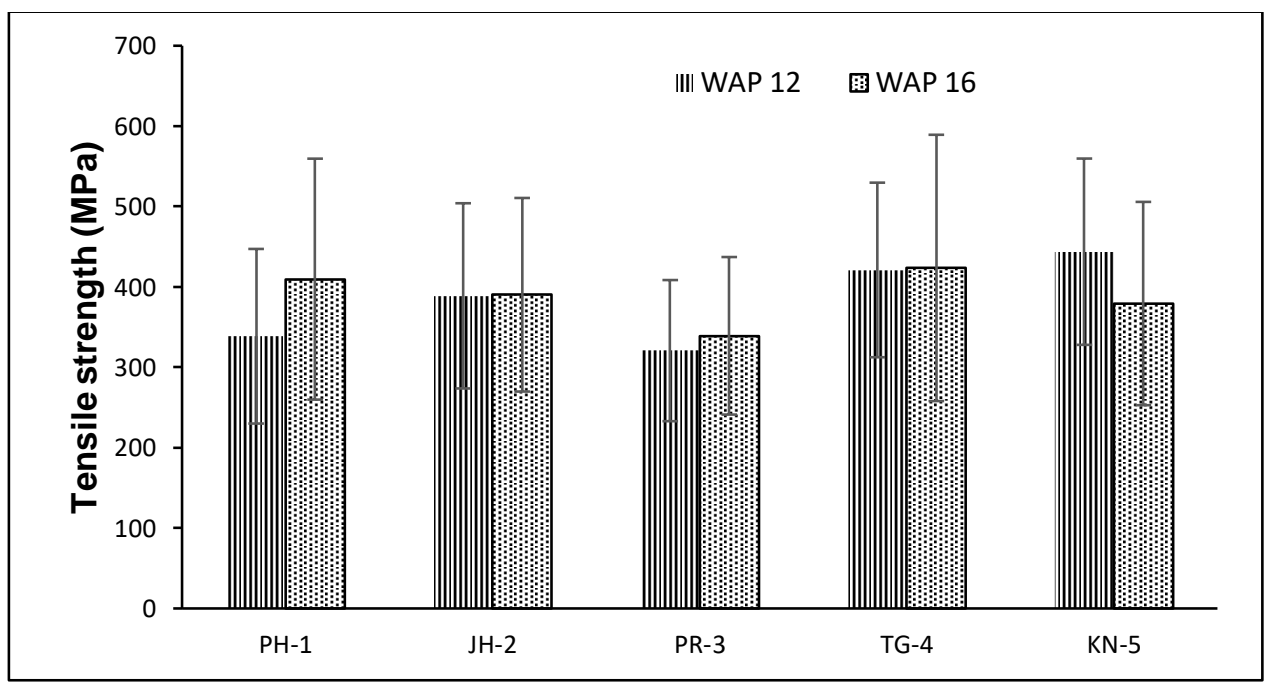

Fig. 7. Tensile strength of kenaf fiber at 12 and 16 WAP

A previous study reported a few contributing factors that also could affect the strength of the fiber are cellulose content, microfibrillar angle, the diameter of the fiber, the defect presence on the fiber, water content inside the fiber (Thakur et al. 2014), the thickness of the secondary cell walls, and the number of elementary fibers in the fiber bundle (Intan et al. 2019). In this case, the tensile strength of the fiber was most probably 
influenced by the diameter, defects, and moisture content in the fiber because there were no significant differences on the cellulose content among all samples.

The results of MR showed that the regain capacity of 16 WAP of kenaf fiber was lower than 12 WAP. Therefore, lesser water content inside the fiber contributed to the higher tensile strength of the 16 WAP kenaf fiber. Very low tensile strength was observed on the kenaf fiber collected from PR-3, which resulted from the retting activities on the processing sites. The kenaf stem was exposed earlier under the sun on the red sand, which primarily can be found only in that state. Furthermore, because the fiber was retted in the tanks, insufficiency of water volume used during the retting process contributed to the low tensile strength of the fiber. This is due to low population of retting microbes in insufficient water volume during retting process, which leads to fiber damage, inferior fiber quality, and longer required retting duration time (NIIB 2001). Like any natural fiber, kenaf fiber showed a relatively large range of tensile strength due to the non-uniform properties compared to the synthetic fibers. Table 6 shows significant values of variables used in this study. The ANOVA $(\mathrm{P}>0.05)$ shows that the location and WAP had no significant effect on the tensile strength of the kenaf fiber where the $P$ values obtained were 0.757 and 0.798 , respectively. However, it was confirmed that the correct time for harvesting is important to obtain the optimum yield and stronger fiber. In the case of the kenaf plant, when approximately ten flowers bloom on the plant, it is the best time for harvesting activities (Rowell and Stout 2007).

Table 6. ANOVA of Kenaf Fiber Tensile Strength

\begin{tabular}{|c|c|c|c|c|c|}
\hline $\begin{array}{c}\text { Source of } \\
\text { Variance }\end{array}$ & DF & SS & MS & F-Value & P-Value \\
\hline Location & 4 & 5918.9 & 1479.7 & 0.47 & 0.757 \\
\hline WAP & 1 & 235.0 & 235.0 & 0.07 & 0.798 \\
\hline
\end{tabular}

\section{CONCLUSIONS}

1. Longer duration in water retting increased the lightness of the kenaf fiber and produced less residual on the physical appearance due to the complete removal of the outer skin bark and impurities.

2. In terms of the quality of kenaf fiber, the water retting process of 10 to 14 days is most suitable for kenaf retting. Efficiency in processing activities produced acceptable physical properties, color, and mechanical strength of kenaf fiber.

3. The fiber from $16 \mathrm{WAP}$ showed lower MR property compared to $12 \mathrm{WAP}$. The lower MR property can be considered advantageous in the production of technical products such as textiles and biocomposite products. Proper processing and good storage activities should be carried out to ensure the absorption of moisture to the kenaf fiber at the lower rate. 


\section{ACKNOWLEDGMENTS}

The authors would like to thank Ministry of Higher Education for the research funding FRGS/1/2018/STG07/UKM/01/1. Also not to forget Universiti Kebangsaan Malaysia (UKM) for the financial support via research project grant DIP-2018-033. Thanks to Fiber and Biocomposite Center (FIDEC), Malaysia Timber Industry Board for the technical support. The authors also would like to extend the deepest appreciation to the NKTB staff for their assistance during the site visit.

\section{REFERENCES CITED}

Abdul, S., Dan, R., and Tan, M. (2001). "Komposisi logam berat di dalam tanih di sekitar Bukit Chuping, Kangar, Perlis [Composition of heavy metal in soil around Chuping Hill, Kangar, Perlis]," Malaysian Journal of Analytical Sciences 7(2), 403-411.

Ang, L. S., Leh, C. P., and Lee, C. C. (2010). "Effects of alkaline pre-impregnation and pulping on Malaysia cultivated kenaf (Hibiscus cannabinus)," BioResources 5(3), 1446-1462. DOI: 10.15376/biores.5.3.1446-1462

Anuar, N. I. S., Zakaria, S., Kaco, H., Hua, C. C., Chunhong, W., and Abdullah, H. H. (2018). "Physico-mechanical, chemical composition, thermal degradation and crystallinity of oil palm empty fruit bunch, kenaf and polypropylene fibres: A comparatives study," Sains Malaysiana 47(4), 839-851. DOI: 10.17576/jsm-20184704-24

ASTM D 1107 - 96 (Reapproved 2001). "Standard Test method for ethanol-toluene solubility of wood," ASTM International, West Conshohocken, PA.

ASTM D2495 - 07. "Standard test method for moisture in cotton by oven-drying," ASTM International, West Conshohocken, PA.

ASTM D3822 - 01. "Standard Test method for tensile properties of single textile fibers," ASTM International, West Conshohocken, PA.

Buddhadeb, B. (2013). "Modern concept of jute retting," in: Advance in Jute Agronomy, Processing and Marketing, PHI Learning Private Limited, New Delhi, India, pp. 108138.

Célino, A., Fréour, S., Jacquemin, F., and Casari, P. (2014). "The hygroscopic behavior of plant fibers: A review," Front. Chem. 1(43), 1-12. DOI:

10.3389/fchem.2013.00043

Chan, C. H., Chia, C. H., Zakaria, S., Ahmad, I., and Dufresne, A. (2013). "Production and characterisation of cellulose and nano-crystalline cellulose from kenaf core wood," BioResources 8(1), 785-794. DOI: 10.15376/biores.8.1.785-794

Chaudhury, J., Singh, D. P., and Hazra, S. K. (2007). "Sunnhemp (Crotalaria juncea, L.)," (https://www.doc-developpement-durable.org/file/Culturefourrages/crotalaria/Sunnhemp.pdf), Accessed 23 July 2013.

Das, B., Chakrabarti, K., Tripathi, S., and Chakraborty, A. (2014). "Review of some factors influencing jute fiber quality," J. Nat. Fibers 11(3), 268-281. DOI: 10.1080/15440478.2014.880103

Dauda, S. M., Desa, A., Abdan, K., and Jamarei, O. (2013). "Performance evaluation of a tractor mounted kenaf," Academic Research International 4(2), 70-81.

Grubben, G. J. H., and Denton, O. A. (2004). "Hibiscus," in: Plant Resources of Tropical Africa 2. Vegetables, PROTA Foundation, NL, Technical Centre for Agricultural and 
Rural Cooperation (CTA), Netherland, NY, USA, pp. 316-320.

H'ng, P. S., Khor, B. N., Tadashi, N., Aini, A. S. N., and Paridah, M. T. (2009). "Anatomical structure and fibre morphology of new kenaf varieties," Asian Journal of Scientific Research 2(3), 161-166. DOI: 10.3923/ajsr.2009.161.166

Hulle, A., Kadole, P., and Katkar, P. (2015). "Agave Americana leaf fibers," Fibers 3(1), 64-75. DOI: 10.3390/fib3010064

Intan, N., Anuar, S., Zakaria, S., Gan, S., Hua, C., Wang, C., and Harun, J. (2019). "Comparison of the morphological and mechanical properties of oil Palm EFB fibres and kenaf fibres in nonwoven reinforced composites," Ind. Crop. Prod. 127, 55-65. DOI: 10.1016/j.indcrop.2018.09.056

Izran, K., Mohd Zharif, T., Beyer, G., Mohamad Jani, S., Noor Azrieda, A. R., and Yanti, A. K. (2014). "Kenaf for biocomposite: An overview," J. Sci. Technol. 6(2), 41-66.

Kamat, J., Roy, D. N., and Goel, K. (2002). "Effect of harvesting age on the chemical properties of hemp plants," J. Wood Chem. Technol. 22(4), 285-293. DOI: 10.1081/WCT-120016263

Mohd, H. A. B., Arifin, A., Nasima, J., Hazandy, A. H., and Khalil, A. (2014). "Journey of kenaf in Malaysia: A review," Sci. Res. Essays 9(11), 458-470. DOI: 10.5897/SRE12.471

Misnon, M. I., Islam, M. M., Epaarachchi, J. A., and Lau, K. T. (2014). "Potentiality of utilising natural textile materials for engineering composites applications," Mater. Des. 59, 359-368. DOI: 10.1016/j.matdes.2014.03.022

Nair, G., Singh, A., Zimniewska, M., and Raghavan, V. (2013). "Comparative evaluation of physical and structural properties of water retted and non-retted flax fibers," Fibers 1(3), 59-69. DOI: 10.3390/fib1030059

National Institute of Industrial Board of Consultant and Engineers (2001). "Mallow family (Malvacae)," in: Natural Fiber Handbook With Cultivation and Uses, National Institute of Industrial Research, Delhi, India.

Pari, L., Baraniecki, P., Kaniewski, R., and Scarfone, A. (2015). "Harvesting strategies of bast fiber crops in Europe and in China," Ind. Crop. Prod. 68, 90-96. DOI: 10.1016/j.indcrop.2014.09.010

Rowell, R. M., and Stout, H. P. (2007). "Jute and kenaf," in: Handbook of Fibre Chemistry, CRC/Taylor \& Francis, New York, NY, USA, pp. 405-452.

Sarkar, S., and Sengupta, K. (2015). "Comprehensive technique for jute fibre retting," International Journal of Bio-resource and Stress Management 6(1), 170-175. DOI: 10.5958/0976-4038.2015.00023.8

Singh, B. P. (2010). Industrial Crops and Uses, CAB International, Wallingford, United Kingdom, pp. 314-324. DOI: 10.1079/9781845936167.0140

Paridah, M. T., Basher, A. B. A., SaifulAzry, S., and Ahmed, Z. (2011). "Retting process of some bast plant fibres and its effect on fibre quality: A review," BioResources 6(4), 5260-5281. DOI: 10.15376/biores.6.4.5260-5281

TAPPI T203 cm-99 (1999). “Alpha-, beta- and gamma-cellulose in pulp,” TAPPI Press, Atlanta, GA.

TAPPI T 222 om-98 (1998). “Acid-insoluble lignin in wood and pulp,” TAPPI Press, Atlanta, GA.

TAPPI T 244 cm-99 (1998). “Acid-insoluble ash in wood, pulp, paper, and Paperboard," TAPPI Press, Atlanta, GA.

Thakur, V. K., Thakur, M. K., and Gupta, R. K. (2014). "Review: Raw natural fiberbased polymer composites," Int. J. Polym. Anal. Ch. 19(3), 256-271. DOI: 
10.1080/1023666X.2014.880016

Tholibon, D., Muhamad, N., Ismail, N. F., Sulong, A. B., Izdihar Tharazi, Radzi, M. K. F. M., Radzuan, N. A. M., and Hui, D. (2019). "Kenaf fiber composites: A review on synthetic and biodegradable polymer matrix," Jurnal Kejuruteraan 31(1), 65-76. DOI: 10.17576/jkukm-2019-31(1)-08

Wang, C., Bai, S., Yue, X., Long, B., and Choo-Smith, L. P. (2016). "Relationship between chemical composition, crystallinity, orientation and tensile strength of kenaf fiber," Fiber. Polym. 17(11), 1757-1764. DOI: 10.1007/s12221-016-6703-5

Webber, C. L., Bledsoe, V. K., and Bledsoe, R. E. (2002). "Kenaf harvesting and processing," in: Trends in New Crops and New Uses, J. Janick, and A. Whipkey (eds.), ASHS Press, Alexandria, VA, USA, pp. 340-347.

Yu, H., and Yu, C. (2007). "Study on microbe retting of kenaf fiber," Enzyme. Microb. Tech. 40(7), 1806-1809. DOI: 10.1016/j.enzmictec.2007.02.018

Article submitted: April 6, 2020; Peer review completed: July 12, 2020; Revised version received: July 22, 2020; Accepted: July 23, 2020; Published: August 3, 2020.

DOI: $10.15376 /$ biores.15.3.7207-7222 